ISSN:2528-9527

E-ISSN : 2528-9535

YIl Year: 8

Cilt Volume: 9

Sayı Issue :16

Uluslararası Toplum Araştırmaları Dergisi International Journal of Society Researches

Aralık December 2018

Makalenin Geliş Tarihi Received Date:27/11/2018

Makalenin Kabul Tarihi Accepted Date: 28/12/2018

\title{
Bryan S. Turner'ın Kuramı Çerçevesinde Kadın, Beden ve Toplum
}

\author{
DOI: $10.26466 / o p u s .488049$
}

\section{Özlem Aydoğmuș Ördem}

*Dr, Öğretim Üyesi, Çukurova Üniversitesi, İletişim Fakültesi, Sarıçam / Adana / Türkiye

E-Posta: ozlemordem@gmail.com

ORCID: 0000-0002-9896-3037

Öz

Sosyoloji disiplininde, beden sosyolojisi alanı ikinci dünya savaşı sonrasına kadar göz ardı edilmiştir. Postyapısalcı kuramla birlikte beden sorgulanmaya başlanmıştır. Dolayısıyla, 1950 sonrası modern sosyoloji teorisinde, insan bedeni merkezde bir bilgi sorunu ve konusu olarak yer almaktadır. Postyapısalcı düşüncede beden ve arzunun önemi çok sık bir şekilde tanınmıştır. Bu çalışmada Bryan S. Turner'ın beden sosyolojisi ele alınmıştır. Ayrıca, kadının toplumdaki yeri beden sosyolojisi açısından incelenmiştir. Çünkü Turner'ın beden sosyolojisi içerisinde en çok yer alması gereken toplumsal aktörün kadın olduğu düşünülmektedir. Turner, beden problemini Descartes'tan günümüze kadar ele alarak beden sosyolojisini disiplinler arası bir bakışla tartışmaktadır. Bedenin toplumsal olarak inşa edildiğini ve iktidarm merkezlerinden biri olduğunu vurgulamaktadır. Turner, bedenleşmenin toplumsal doğası ve karşıllklılık ilişkisine dayanarak uygarlaşma süreci ile birlikte beden ve kültürel oluşumu anlayışı ve beden teorisi daha yakından incelenerek bütünsel bir yaklaşıma doğru gidilmesi gerektiğini düşünmektedir. Günümüzde Turner'n beden sosyolojisi ile ilgili analizleri toplumda sağlık sosyolojisinin gelişmesine katkıda bulunmuştur ve genel sosyolojide unutulan beden sosyolojisi problemini derinleştirmiştir.

Anahtar Kelimeler: Beden, toplum, Bryan S. Turner, kadın, postyapısalcıllk, sağlık sosyolojisi

OPUS (c) Uluslararası Toplum Araştırmaları Dergisi-International Journal of Society Researches ISSN:2528-9527 E-ISSN : 2528-9535

http://opusjournal.net 


\title{
Women, Body and Society within the Framework of Bryan S. Turner's theory
}

\begin{abstract}
The discipline of sociology ignored body until after the Second World War. The body has been questioned and examined within the poststructuralist theory. Therefore, in the post-1950 modern sociology theory, the human body has been scrutinized as a problem and subject of knowledge in the center. The importance of body and desire in poststructuralist thinking is very often recognized. In this study, the sociology of the body developed by Bryan S. Turner has been discussed. The role of women has also been investigated within the framework of sociology of body because it is women as social actors that should be placed into Turner's theory of sociology of body. Turner dealt with the sociology of bodies from an interdisciplinary point of view, taking the body problem from Descartes to the present. It is emphasized that the body is socially constructed and can be seen as one of the centers of power. Turner (2001) notes that based on the relationship between social nature and reciprocity of the body, together with the process of civilization, body and cultural formation, and body theory should be examined more closely approaching a holistic approach. Turner's analysis of the sociology of the body has contributed to the development of the sociology of health in the society and has deepened the problem of the sociology of the body which has been discarded in general sociology.
\end{abstract}

Keywords: Body, society, Bryan S. Turner, women, poststructuralism, sociology of health

OPUS (c) Uluslararası Toplum Araştırmaları Dergisi-International Journal of Society Researches ISSN:2528-9527 E-ISSN : 2528-9535

http://opusjournal.net 


\section{Giriş}

Pozitivist ilkeler çerçevesinde kurulan ve evrensellik iddiası olan sosyoloji, zamanla bireyleri de içine alan mikro sosyolojiyi geliştirmek zorunda kalmıştır. Sosyoloji disiplini ister makro ister mikro düzeyde olsun belli aktörleri bu süreçte unutmuştur. Farklı kimliklerin, çocukların ve özellikle kadınların sosyolojide uzun süre göz ardı edilmesi başka önemli konuların da ihmal edilmesine yol açmıştır. Durkheim, Weber ve Marx gibi sosyologların evrenseli inşa etme fikri özellikle 1960'dan sonra eleştirilmeye başlanmıştır (Turner, 1992, 2001). Bu açıdan Frankfurt Okulu da Marx çevresinde düşüncesini olgunlaştırdığı için belli sorunları görmezden gelmiştir. İki dünya savaşının yaşanması sosyolojiyi çok derinden etkilemiştir. Çünkü iki dünya savaşında aslında yok olan bedenler olmuştur. Sosyolojinin en yakını olduğu beden, sosyolojinin çalışma alanları içerisinde olmayınca tarihsel süreç, bedenin tanınmasını bir anlamda zorunlu hale getirmiştir.

Aslında, sosyoloji disiplini kurumlar, gruplar, topluluklar, toplumsal değişme ve gelişme aşamalarının bilimsel olarak araştırılması olarak tanımlanmasına rağmen, zorunlu olarak bireyi, bireyin davranışlarını, deneyimlerini, doğasını bütünsel anlamda ele almak zorunda kalmıştır. Toplumda insanların birer birey oldukları düşünüldügüunde, sosyoloji bilimi bireyin toplumsal yaşamdaki etkileşimi, eylemleri, tercihleri, yorumları, aldığı ve verdiği kararların toplamından oluşan özelliklerinin araştırılması olarak da tanımlanabilir. Toplumsal bireye anlam katan bütün bu seçim ve yorumlama eylemleri toplumsal olgular olarak da ele alınabilir. Bundan dolayı, sosyolojide bireyi ve toplumu ilgilendiren bazı temel yaklaşımlar hem toplumsal eylem hem de toplumsal sistemleri kapsadığı için çoğunlukla eylem sistemleri yaklaşımları olarak adlandırılır (Turner, 2001, 2011). Fakat bu iki yaklaşım yine de bedeni tamamen görmezden gelmektedir.

\section{Beden Sosyolojisinin Ortaya Çıkışı}

19. ve 20. Yüzyılın ortalarına kadar sosyoloji büyük oranda fen bilimleri, Darwinizm, biyolojizm ve üst anlatıların etkisi altında kalmıştır (Turner, 2001). Endüstrileşme ve kentleşme daha çok kapitalizmin ilkeleri 
çerçevesinde yorumlanmıştır. Descartes' 1 n $(2011,2018)$ da düalist felsefesinin etkisiyle beden, sosyal bilimlerden aslında tamamen kopartılmıştır. Bilişsel sinirbilimin, evrimsel psikolojinin, yapılandırmacı yaklaşımların, bilişsel dil bilimin, bedenleşmiş bilişin, beyindeki duygu merkezlerinin keşfi, modernitenin eleştirisi ve postyapısalcılı̆̆ın ortaya çıkışıyla birlikte Descartes'ın (2011) yarattı̆̆1 dikotomi, sürekliliğe çevrilmiştir. Beden, beyin, zihin, duygu ve yorumlama arasında bir sürekliliğin olduğu vurgulanmıştır. Dolayısıyla, Turner'ın sosyolojide geliştirdiği beden sosyolojisini önceleyen birtakım gelişmeler meydana gelmiştir. Sosyoloji, diğer disiplinlerde ortaya çıkan yeni gelişmelere tepki vererek daha önce sosyoloji disiplininde görülmeyen yeni bir alana doğru yol almaya başladi. Bu yeni bedenin ya da bedenlerin sosyolojisi idi. Merleau Ponty (1962) ve Foucault $(1993,2003)$ ile başlayan bu süreç, Turner'da (2001) detaylı bir kurama ulaşmıştır. Turner, tüm tarihsel süreci yapıcı bir eleştiri ile ele alarak unutulan bedeni sosyolojiye kazandırmıştır (2001, 2011). Özellikle tıp alanında bedenin düzenlenmesi sağlık sosyolojisinin gelişmesine katkıda bulunmuştur. Turner, bu anlamda büyük oranda Foucault'nun $(2011,2015)$ söylemlerinden ve fikirlerinden etkilenmiştir. Çünkü Foucault (2011), bedenlerin psikiyatri ve hukuk söylemleriyle eş zamanlı ilerleyerek hapsedildiğini belirtir. Psikiyatrinin söylemlerinin hukuk alanını da etkilediğini belirterek bedenlerin hapsolduğunu vurgulamaktadır. İstenmeyen bedenler toplumda yer alamazlar ve hasta olarak etiketlenirler.

Dolayısıyla, sonraki yıllarda Foucault ile başlayan tıbbın özellikle psikiyatrinin bedeni nasıl kontrol ettiği ile ilgili düşünceler Turner'ın beden ve toplum ilişkisini açıklamada etkide bulunmuştur (2011). Aynı zamanda bedeni kontrol etme anlayışı sağlık sosyolojisinin de ilgi alanını oluşturmuştur. Tıp ve sosyal bilimler alanlarının uzun bir süre birlikte gelişmesi, sürekli olarak akıllaştırma çabasının bir uzantısı olmasıdır. Örneğin, 19. Yüzyılda kentleşme ve nüfus hareketliliğinin yaşanması sebebiyle, şehirlerde sağlık ile ilgili verilerin toplanması dikkatli olarak başlatılmıştır. Sosyoloji bilimi, özellikle insan eylemleri ile ilgili her şeyin akla dayandırıldığı sistemleri eleştirerek ve aşırılıktan kaçınarak gelişme göstermeye çalışmıştır. Sosyoloji düşüncesinin merkezinde insanların dünyasının sosyal ve kültürel olarak kurulduğu ve dönüştürüldüğü ilkesi vardır. Toplumsal etkileşimde insan karşılılık ilkesinden hareketle 
dünyayı kültürel ve çevresel olarak anlamlandırır. İnsan bedeni de, olduğu gibi değil, kültür ile yorumlanan tarihsel bir gerçekliktir. Doğa insanın dışında kalan değildir, tam tersi insan bedeni ile bütünleşen, emek verilen kültürel bir olgudur. İnsan bedeninin gerçekliği, insanın aklı ve tecrübesinin sınırlı bir noktası olarak kendinin yerleştiği sosyal dünyanın kolektif gerçekliğinden daha az önemli görülmekteydi. Turner (2001), Ben-toplum dikotomisine vurgu yaparak, klasik sosyolojinin doğa-toplum ikilemini reddeder çünkü doğa-toplum ikilemi 19. Yüzyılda Darwinizm ve biyolojizimden kaynaklanan bir paradigma olarak görülmekteydi. Oysa 1950 sonrası çalışmalarda birey, ben, beden ve toplum önem kazanmaya başlar (Butler, 1988, 2008; Schilling, 1993; Williams ve Bendelow, 1998) Birey önem kazansa da mikro sosyolojide beden unutulur. Bu riske karşı Turner (2001) bireyin içine bedeni geri kazandırır ve hatırlatır. Bedensiz bireylerin ve öznelerin sosyolojisine karşı bir duruş sergiler. İster makro ister mikro düzeyde olsun bedensiz toplum ve bedensiz birey artık sosyolojide yer alamaz konuma getirilmiştir. Turner (2001), sosyolojiyi uygulamalı tıp olarak görürken aslında sorunun ne kadar radikal olduğunu vurgulamaktadır. Çünkü Foucaultcu anlamda bedenler tüm tıp bilimi tarafından kontrol edilmektedir ve bir güç olarak ortaya çıkmaktadır. Tıp biliminin ve ilaç sanayinin kapitalizmle ilişkisi göz önünde bulundurulduğunda o zaman kapitalizmin popüler kültür anlamında da bedenleri nasıl kontrol altına aldığı görülebilir. Bedenler söylemlerle ve uzman hekimlerle şekillendirilir. Tıp, bedenlerle ilgili devamlı yeni söylemler geliştirir ve modalar oluşturur. Bedenler, geçici moda nesneleri olarak görülür. Sosyoloji disiplini, beden sosyolojisi çalışmalarını son zamanlarda yoğun olarak ele almaya başlamıştır. Sosyolojik teori içerisinde önemli tartışmalardan olan akıl ve insanın arzuları ikiliği beden sosyolojisi alanında tartışılmaktadır. Ancak bu konu beden sosyolojisi teorisinde yeterince ve sistematik bir şekilde incelenmemiştir. Sosyoloji disiplininde insan bedeni fen bilimlerinde ayrı bir bilgi konusu olarak yer almaktadır. Beden ve arzu ikilemi, modern yapısalcı düşüncede sık bir şekilde tartışılmaktadır.

Foucault $(1993,2003)$, bedenin sorgulanmasının tarihsel analiz ile ele alınması gerektiğini ifade eder. Geleneksel felsefe ve sosyal teoride güç arzuyu bastırmak için vardır, oysa Foucault (2011) iktidara yapıcı ve üretici olarak bakar. Arzu iktidar/bilgi ile yeniden yaratılır ve güç söylemleri 
ile gündeme getirilir. Modern toplumlar bedeni cinsel bastırılma ile ifade ederken, aslında cinsellik çağdaş söylemlerle devamlı üretilir ve incelenir. Fakat bunlar tıbbi ve psikiyatrik işlerin kontrolü altında yürütülür. Bilme arzusu, cinselliği bilme arzusudur ve bilmek kontrol etmektir. Cinsel beden, politikanın özel bir nesnesi olur. Marcuse'e (2013) göre, kapitalist sistemde cinsiyetin/seksin bastırılması gerçekliktir ve bedensel zevklerin bastırılmasının belli bölümlerini oluşturur. Foucault (1993) için cinsel bastırma bir mittir çünkü seks aslında sonsuz bilimsel söylemlerin psikoanaliz, demografi, biyoloji, medikal bilim- nesnesi ve ürünü olur ve bu da cinselliği kontrol ve normalize etmeyi amaçlar. Bilgi arzuyu kontrol etmek için arzuyu üretti. Bu bakımdan Foucault (1993) arzuya tarihte bütünleşmiş bir fenomen olarak davranma tehlikesinden kaçınır. Çünkü o arzuya belli tarihsel söylemlerin ürünü olarak yaklaşır. Fakat bu Foucault'nun teorisinde belirsizlik yaratır. Zaman zaman bedene gerçek bir varlık olarak yaklaşır. Foucault (1993), bedeni, çağlar boyunca sürekliliği olan insan tarihinin birleşik ve somut özelliği olarak görür. Fakat bu durum Foucault'nun (Turner, 2001) tarihin süreksizlik fikriyle çelişmektedir ve tartışmasında beden söylem ile kurulur. Foucault (2003, 2011), Turner'ın beden sosyolojindeki kavramsallaştırmaya uygun olarak ideoloji yerine bedenin merak edilmesini, sorgulanmasını ve iktidarın beden üzerindeki sonuçlarını tartışmayı tercih eder. Bu tür bir materyalist yaklaşım yaşamın bedenselliğini ciddiye almak olacaktır. Turner (2001), bedenin ne olduğu sorusunun Foucault'nun düşüncesinde temel bir soru olduğunu fakat açık bir şekilde cevaplanmadığını ifade etmektedir.

Turner (2001), Foucault'nun da sosyolojiyi bir anlamda uygulamalı tıp olarak gördügünü ve hedefinin bedenleri düzenlemek olduğunu vurgulamaktadır. Bu anlamda sağlık sosyolojisi, insan bedenlerinin bedenselleşmesi durumu ile ilgili sorunları gündeme getirmektedir. Turner'ın (1992, 2001) sağlık sosyolojisi üzerindeki önemi sağlık sosyolojisinin teorik doğasını daha açı kılmaktadır. Aynı zamanda, dikkatimizi tıp ve sosyoloji arasındaki tarihi ve politik ilişkiye çekmiştir. Bedenin sosyolojisi böylece temelde sağlık sosyolojisi içerisinde yer almaktadır. Turner (2001), beden sosyolojisi ile ilgili araştırmaların çok farklı alanlarda yapıldığını, ancak tam anlamıyla teorik bir bütünlügün olmadığını vurgulamıştır. Beden ile ilgili çalışmalarda farklı alanlarda bir ilerleme sağlandığını belirtmiştir. Bedenlerin davranışsal anlamda etkileşimi sosyal ve kültürel 
inşalardır. Beden sosyolojisinin ilgi alanında bu olduğu söylenebilir. Toplumsal etkileşim birçok alanın bir ürünüdür ve devamlı ortaya çıkan bir gerçekliktir. Dolayısıyla insan ve bedeni sosyal ve kültürel olarak kurulmuş varlıklardır. Ben ve beni imgesi, sosyal etkileşim aracılığı ile karmaşık bir bütündür. Toplumsalın sosyal, kültürel ve tarihsel olarak kurulmuş doğası üzerindeki 'ben'vurgusundan çok 'beni' vurgusunu ortaya çıkarmaktadır. Dolayısıyla, toplumsal olanda ben vurgusu önemsiz ve sonuçsuz kalmaktadır. Makro sosyolojide sosyal sınıflar ve politik partiler aile ve ekonomi arasındaki ilişki ile ilgilendiği için, insan bedeni bu durumda makro sosyolojide ele alınamaz, yer bulamaz. Mikro-sosyoloji ise bedeni dışlamaktadır. Çünkü beden, bir özne olarak eylem içerisinde sosyal ve kültürel olarak kurulmuştur (Turner, 2001).

Turner (2001), toplum bilimlerin insan bedenine ilişkin önemli bir düşünce geliştiremediklerini iddia etmektedir. Turner (1992), bedene ilişkin iki farklı düşüncenin ortaya çıtığını belirtmektedir. Birinci görüşe göre, beden kimilerince yaşanan bir tecrübedir. Kültürel çevrede gündelik hayatın ve biyolojinin toplumsal bedeni nasıl etkilediğini incelemek karmaşık bir süreçtir. İkinci görüşte yer alanlar ise, bedeni toplumsal ilişkileri ve etkileşimleri dile getiren bir söylem olarak ele almaktadır. Açıkçası bedeni bir semboller sistemi olarak görürler. Toplumsal yapının bütününü anlama, beden hareketlerinin anlaşılması ile mümkün olacaktır. Bu yaklaşıma göre, beden toplumdaki bilginin, gücün ve söylemin yapılanmasından oluşmaktadır.

İnsan bedenine yönelik birçok yaklaşım, postmodernist söylemle beraber bireyi daha çok merkeze almaya başlamıştır. Postmodernizme göre, sağlık, eğitim, aile gibi kavramların anlamı daha da derinleşmeye başlamıştır (Featherstone, 2005). Turner (2011) benzer kavramları vurgulayarak hastalık kavramının sorunlu olduğunu belirtir. Örneğin, hastalık kavramından çok, tüketim ve sağlık kavramına doğru bir kültürel değişim yaşanmaktadır. Bu yeni dönem sağlık alanında kendini çeşitli sekilerde göstermektedir. Özellikle modernleşmeyle birlikte, kadınlar yaşamış oldukları sağlık sorunlarını ve kendi bedenleri üzerindeki baskıyı kendileri çözmeye çalışmaktadır. Alternatif tıp sadece gelişmiş ülkelerde değil azgelişmiş ülkelerde de oldukça yaygınlık kazanmakta ve kabul görmektedir. Medya tarafından doktorlar sağlık sorunlarına çözüm getiren araçlardan sadece birisi olmakta ve tıp bilimi de birçok kimsenin 
büyük saygınlık duyduğu bir disiplin olmaktan çıkarak, sağlığa ilişkin sadece bir "söylem" durumuna düşmektedir. Sağlıklı yaşam ile ilgili temel paradigma toplumsal sistemin uyulması istenen bir olgu olarak karşımıza çıkmaktadır. Tıp bilimi ve medya ile birlikte toplumsal sistemin uygulanabildiği en önemli alan kadın bedeni olmuştur. Sağlıklı yaşamın temel paradigması kültürel normlara uyumlu, politik anlamda sessiz ve davranışsal olarak da kısıtlı bir bedenleşme olmasıdır. Bu paradigmaların görünümü daha çok kadın bedeninde kurulmaktadır. Göle (2004), kadınların yaşam biçimlerinde bedenlerini görünür kılan en önemli olgunun örtünme sembollerinin olduğunu ifade etmektedir. Modernleşmeyle birlikte bu semboller farklı kültürlere göre toplumdaki bedenleşmenin kendine farklı kamusal alanlar yaratmaktadır. Toplumsal sistemde politika, kültür, sağlık ve medya tarafından kadın bedeninin sahiplenilmesi gibi farklı sorunları ortaya çıkarmıştır.

\section{Kadın Bedeni ile İlgili Sorunsallar}

Tarihsel süreçte kadın ile ilgili çalışmalara bakıldığında daha çok aile sosyolojisinin bir alt alanı olarak ele alındığı görülebilir. 20. Yüzyılın kadın ile ilgili çalışmaları, kadının oy kullanma hakkı, mülk edinme, çocuğunun velayetini alma, boşanabilme gibi konuları ele almaktadır. Kadının bedensel bir aktör/özne olarak ele alınması çok geç tarihlere rastlamaktadır (Butler, 1988,2008; Göle, 2007; Martin, 1989; Williams ve Bendelow, 1998). Kadının anneliğinden bağımsız olarak kendi varlığına dair sorgulaması, düşünmesi, bedenini inşa etmesi fenomenolojik bir yaklaşımla öngörülebilir. Fenomenolojik gelenek nesnel araçsal beden ile öznel yaşayan beden arasında önemli bir ilişki kurmuştur (Honneth ve Joas, 1988). Bedenleşme fikrine göre tüm temel kavrayış, algı, değerlendirme ve karar verme süreçleri insanların bedenleşmiş toplum olmalarına bağlıdır (MerleauPonty, 1962). Turner (2001), beden sosyolojisini sosyolojinin özel ya da alt bir alanı olmadığını ve birincil öneme sahip olduğunu vurgulamıştır. Turner'a (2011) göre, insanlar öylesine bir bedene sahip değillerdir. İnsanlar bedenleri ile ilgili söz söyleme hakkına sahiptirler ve bedenlerinin gelişimiyle ilgilenmek zorundadırlar. İnsanlar bundan dolayı bedenlerdir. Kadın bedenine dair olan söylem alanının yoğunluğu dikkat çekicidir ve beden tahakkümler altındadır. Kamusal alanda beden ifade edildiğinde 
zihinsel bir alışkanlık olarak kadın bedeni gelmektedir. İdeolojilerin, hukukun, politikanın, iletişimin, işletmelerin ve hatta bilimin sınırlandırdığ 1 insan ve bedeni işlevsel ve yapısal olarak ele alınmaya çalışılmaktadır (Göle, 2000, 2002, 2004). İşlevsel beden gündelik yaşam pratiklerini sürdürebilen, uyum gösterebilen, oy kullanan, çevresinden bağımsız hareket etmeyen bir bedeni ifade ederken; yapısal beden ilerleme, gelişme, dönüşmeyi anlamsız bulan statik bir yapısal alanı göstermektedir. Kadın bedeni iktidar, güç, prestij ve medyadan bağımsız olarak düşünülememektedir. Özellikle tüketim kültürü içerisinde sosyal medyanın sorumluluğu altında kadın bedenine dair bir söylem alanı oluşturmaktadır (Featherstone, 2005). Beden doğası gereği irrasyonel ve davranışsaldır. Bundan dolayı kadınlar toplumsal statü sembollerine, dürtülere, politik temalara irrasyonel ve duygusal tepkiler vermeye eğilimlilerdir. Beden sosyolojisi bu irrasyonelliği söylemsel tahakkümden çıkararak göstermelidir. Güç, siyaset ve medyanın elinde bulundurduğu prestijden dolayı, bir beden sosyolojisi bilimciliği geliştirme riski taşımaktadır. Bu durumda Durkheim'ın (1984) kavramsallaştırdığı anomi, bedenin anomisi sendromunu ortaya çıkarabilir. Bedene ya da bedenlere sahip olma insanı bedenselleşmeye götürebilir ve bu durum kültürel, tarihsel beden anlayışını arka plana itebilir. Kamusal alanın dışında yer alan özel hayata dair bir beden tanımı aslında bilinmezliklerle doludur. İnsanın özellikle de kadının gündelik yaşamında karşılaştığı güçlüklerle baş etme yöntemleri karmaşık ve oldukça güçtür. Kadın bedeninde ağır basan bu karmaşık duygu sadece bilebildikleri ve kavrayabildikleri kadardır. Çünkü bedeni aile ve komşuluk ilişkileri gibi dar kalıplarla sınırlıdır ve kendi yaşamını kontrol edebilecek politik bir güçten yoksundur. İnsanların güç ve otorite yapılarını ele geçirdikleri, kullandıkları ve etkiledikleri bir yapı olan politika düzeni ile mal ve hizmetleri üretmek ve dağıtmak için emeği, kaynakları ve teknolojiyi kullanan bir yapı olan ekonomik düzen tamamıla beden/bedenleri de düzenlemektedir. Güdülenmiş bedenlerin hareket ve kontrol alanı kamusal alandır. Güç/iktidar kamu üzerinde örtük ya da kapalı olarak baskı sahibi olan, davranışları biçimlendiren ve sürekli denetleyendir. Marx'ın ifadesiyle bu beden/bedenlerin yabancılaşması olarak yorumlanabilir. Batı ile tanımlanan modernleşme, bedenin kendini ifade etmesini zorlaştırmaktadır. Çiftçi elde ettiği ürünle, esnaf kendi çaba ve emeğiyle yaptığı girişimi, doktor tedavi ettiği hastasıyla bir tatmin 
yaşayabilir. Ancak kapitalist sistemde giderek beden daha da anlamsızlaşmaktadır. Birey kendini bedeni ile ifade edemediğinde özellikle de kadınlar, kendilerine, doğaya ve sürece yabancılaşmaktadır. Sağlık sosyolojisinde tartışılan bedenlerin medikalleştirilmesi ile yaşanan bu yabancılaşma, kadının iç dünyasına yansımaktadır. Bedene dair geçici heyecan ya da mutluluklar yaşamak, gerçek, derinliği olmayan geçici ilişkiler kurmak, zihinsel ve bedensel rahatlığın yaşanmadığ 1 bir yabancılaşma sorunudur. Tarihsel süreçte bedenine yabancılaşan kadın, kamusal alandan bağımsız, güçler tarafından zorlanmadan kendi bedenini kontrol etmekten yoksundur. Bu sorunun temelinde yoksulluk, ekonomik bunalım, eğitimsizlik, savaş gibi büyük problemler yatmaktadır. Günümüzde ekonomik gücü iktidardan ayırmak çok zordur. Özellikle endüstrileşme ve modernleşme ile birlikte kadın bedeni üzerinde daha çok tartışmalar ortaya çıkmıştır. Toplumsal sistem, kadınların bedenlerini rolleri üzerinden biçimlendirmektedir (Parsons,1951). Toplumsal yapı içerisinde yer alan aile, eğitim, sağlık, hukuk, politika ve dinde verili olan bedensel roller sosyolojik açıdan kadınların yaşam pratiklerini de belirlemektedir.

İkinci Dünya Savaşı'ndan sonra evrensellik düşüncesine yönelik eleştiriler ortaya çıkmaya başlamıştır. Özellikle kadın bedeni üzerinden tartışılan kimlik bunalımı/krizi evrensellik düşüncesine yönelik bir eleştiridir. Feminist ve 1968 hareketleri kadın kimliği ile ilgili birçok farklı alanda tartışmaya yol açmıştır. Küreselleşme fikri gibi tarihsel olaylar etnik, dinsel ve cinsel kimlikleri ön plana çıkarmaya başlamıştır (Butler, 1988, 2008; Martin, 1989; Williams ve Bendelow, 1998). Postmodernizm ve postyapısalcılıkla birlikte bir taraftan insanın tanımı farklı biçimlerde yapilırken, diğer taraftan toplumsal cinsiyet kimliğinden bağımsız bir erkeği temel alan görüşler de ortaya çımıştı (Butler, 2008; Featherstone, 2005). Bu durum kadınların sorunlarına örtük biçimde duyarsız kalarak, devleti oluşturan çoğunluğun etnik ve ulusal aidiyetlerini yansıtan üst kimlikleri onayliyordu. Butler'a (2008) kimlik toplumsal söylemlerle ancak kendini var edebilir. Bu anlayışa göre, kadın ve erkek arasındaki eşitsizlik doğal değil, toplumsal nedenlerden ötürü olduğudur. Butler'a göre, toplumsal cinsiyet performatif bir pratiktir ve toplumsal cinsiyetli özne toplumsal normlara göre belirlenir. Tarihsel ve toplumsal bir konu olan cinsiyetlendirilmiş kimlikler daha çok kadın bedeni üzerinden 
sürdürülmektedir (Butler, 2008; Martin, 1989). Örneğin, evlilik, aile gibi toplumsal konular toplum tarafindan onaylanan cinsel birliktelikleri ifade eder ve aynı zamanda kurumsal olmasını sağlar. Tarihsel süreçte, toplum içerisinde yer alan belli başlı ritüeller, kültürel normlar kadın bedeni üzerinden tartışılarak oluşturulmuştur. Çünkü kültürel kuralların belli tahakkümlerle daha çok kadın bedeni üzerinde uygulanması toplumun daha az avantajlı bireyleri olarak görülmesinden kaynaklanmaktadır. Gelişmenin ve değişmenin çok yavaş olduğu toplumlarda kadın bedeninin daha kapalı ve eşit olmayan koşullarda kendini kurmaya çalıştı̆̆1 görülmektedir (Göle, 2009, 2015). Sahip olduğu beden ancak kendini yasalarla ve sorumlu olduğu haklarla koruyabilir. Belli toplumsal kuralların sınırlı bir şekilde yerine getirilmesi, aslında bedenin tahakküm alanından çıkma mücadelesidir. Göle ( 2015), bu durumu Batı toplumlarında yaşayan Müslüman kadınlar üzerinden vermeye çalışır. Göle (2004, 2009) Müslüman kadının bedenini mahremiyet çerçevesinde ele alarak modernite içinde yorumlamıştır ve batı-dışı modernlik kavramıyla aslında bir anlamda görünür olanın, yani bedenlerin batı toplumlarını kendilerini yeniden yorumlamaya ittiğini belirtmektedir. Batı-dışı modernlik kavramı bir anlamda bedenlerin görülebilirliği sayesinde ortaya çıkmıştır (Göle, 2007). Bu genelde örtünen Müslüman kadınların bedenidir ve görülebilir alanlarda yaşamaktadır. Endüstrileşme sonrası modernleşme ve kentleşme ile birlikte gelişmişlik ya da az gelişmişlik meselesi beden/bedenlerin de özgürlük alanlarını belirlemektedir. Tarihe ve kültüre göre değişen özellikle kadının beden algısı kendisini toplumsalın içinde kurmakta ve kurmaya devam etmektedir. Eğitim, demokrasi, hak ve özgürlüklerin yaygınlaşması, fırsat eşitliğinin yaratılması, özel girişimcilik gibi insanı güdüleyen değerlerin yaygınlaşması ile beden/bedenleri örtük değil açık bir şekilde kamusal alanda görünür k1lacaktır.

\section{Sonuç}


Turner (2001), Descartes ile başlayan düalizmin 1960'tan itibaren bir süreklilik alanına dâhil edilerek bedenin sosyolojiye kazandırılması gerektiğini düşünür. Böylece, sosyolojideki ikilikler, farklılıklar ve süreklilikler alanına dönüşür. Özellikle Foucault ile başlayan beden sosyolojisi aslında Turner'da (2001) bir anlamda derinlemesine kuramsallaştırılmıştır. Foucault'nun (1993) tarihsel süreçte tıp söyleminin etkili olduğunu vurgulayarak doğrudan ya da dolaylı olarak akıl hastanelerinin ve hapishanelerin ortaya çıkış ilkelerini şekillendirdiğini belirtmektedir. Ayrıca söylemlerin bedeni belirlediğini araştırmaya çalışır. Tıptaki söylemler nüfusların denetlenmesine neden olur. Turner (2001) klasik sosyolojide bedenin unutulduğundan bahseder. Mikro sosyolojinin bireyi merkeze almasına rağmen bedeni büyük oranda göz ardı ettiğini ifade eder. Sosyolojide bedene vurgunun 1960'lardan sonra başladığını önemle vurgular. Aslında Turner'in $(1992,2011)$ belirlediği bu dönem yapısalcılığın ve modernitenin eleştirilmeye başlandığı yılları kapsamaktadır. Hatta Turner (2001) Foucault'nun düşüncesine uygun olarak sosyolojinin uygulamalı tıp olduğunu vurgular. Dönemlere göre tıp söylemleriyle hastalıkların üretildiğini ifade eder. Günümüzde bedenlerin daha fazla panoptikon altında olduğunu vurgular. Özellikle tıp alanında farklı disiplinlerin ve uzmanlıkların ortaya çıkması bedenlerin yeniden düzenlenmesine neden olmuştur. Bedenler bir anlamda devamlı kontrol edilerek yaşamlar medikalleştirilmiştir. Endüstrileşme, kentleşme ve modernleşme ile gösterilmeye çalışılan kadın bedeni, aslında mikro sosyolojik bakışla gündelik yaşamda ötekileştirilmiş bir bedendir. Geleneksel ve modern kültürler gibi zihinlerde yapılan ayrımcılık ve dışsallaştırma bedenlerde de yapilmıştır.

Turner, ayrıca klasik kuramcı Marx, yabancılaşma kavramı ile birlikte bedenin tekrar ön plana çıkarılıp yeniden yorumlanabileceğini göstermeye çalışmıştır. Ayrıca modern ve postmodern anlamda beden sosyolojisi çalışmaları, Nietzche ve Foucault'yu temele alarak bir bedenler sosyolojisi analiz edilmeye çalışılmaktadır. Beden sosyolojisinde Turner (2001) daha çok karşılıklılık ilişkisini kavramsallaştırarak sosyolojinin etkileşim anlamına vurgu yapmakta ve bedenin böyle bir anlayış içerisinde analiz edilebileceğini belirtmektedir. Turner (2011) ile birlikte bedensiz bir sosyolojinin olamayacağını görmekteyiz. Gelecekteki çalışmalarda kadın, kimlik, cinsiyet, kültürel çalışmalar, eğitim aktörleri 
(öğrenciler, öğretmenler, yöneticiler) beden sosyolojisi çerçevesinde yeniden yorumlanmalıdır. Turner'ın (2011) beden sosyolojisi yüzyıllardır süren bedenin unutuluş tutsaklığından bir kurtuluşu önermektedir. Kadının bedeninin, beden(ler) sosyolojisi içerisinde özcü olmayan bir türde dönüştürülmesi Butler'ın (2008) bahsettiği cinsiyet performativitesinin daha iyi anlaşılmasını sağlayabilir. Dolayısıyla, Foucault (1993, 2003), Butler (2008) ve Turner'de $(2001,2011)$ bedenler, söylem pratikleri ile şekillenmektedir ve bu şekillendirmeye söylemlerle itiraz edilebilir. Bu anlamda, kadınların kendi söylemlerini yaratabildikleri ve kendilerini ifade edebildikleri kamusal alana ve platformlara ihtiyaçları vardır. Butler'cı anlamda ifade edecek olursak unutulan farklı bedenler ve kimliklerdir. 
EXTENDED ABSTRACT

\title{
Women, Body and Society within the Framework of Bryan S. Turner's theory
}

\author{
Özlem Aydoğmuş Ördem
}

Çukurova University

The discipline of sociology ignored body until after the Second World War. The body has been questioned and examined within the poststructuralist theory. Therefore, in the post-1950 modern sociology theory, the human body has been scrutinized as a problem and subject of knowledge in the center. The importance of body and desire in poststructuralist thinking is very often recognized. In this study, the sociology of the body developed by Bryan S. Turner has been discussed. The role of women has also been investigated within the framework of sociology of body because it is women as social actors that should be placed into Turner's theory of sociology of body. Turner (2011) dealt with the sociology of bodies from an interdisciplinary point of view, taking the body problem from Descartes to the present. It is emphasized that the body is socially constructed and can be seen as one of the centers of power. Turner (2011) notes that based on the relationship between social nature and reciprocity of the body, together with the process of civilization, body and cultural formation, and body theory should be examined more closely approaching a holistic approach. Turner's analysis of the sociology of the body has contributed to the development of the sociology of health in the society and has deepened the problem of the sociology of the body which has been discarded in general sociology.

Until the mid-19th and 20th centuries, sociology has been largely influenced by science, Darwinism, biology and meta-narratives (Turner, 2011) Industrialization and urbanization have been interpreted mostly within the framework of the principles of capitalism. With the emergence of cognitive neuroscience, evolutionary psychology, constructivist approaches, cognitive linguistics, embodied cognition, the discovery of emotion 
centers in the brain, critique of modernity and poststructuralism, the dichotomy created by Descartes (2011) has been transformed into continuity. It is emphasized that there is continuity between body, brain, mind and emotion. Therefore, there have been some developments prioritizing the sociology of Turner, which he developed in sociology. Sociology reacted to new developments in other disciplines and started to move towards a new area that was not seen in sociology. This was the sociology of the new body or bodies. This process, which started with Merleau Ponty (1962) and Foucault (1993, 2003), reached a detailed theory developed by Turner (2001). Turner, the whole historical process with a constructive criticism of the body has been brought to the sociology of forgotten (2001, 2011).In particular, the organization of the body in medicine has contributed to the development of the sociology of health. In this sense, Turner was largely influenced by the discourses and ideas of Foucault (2011, 2015). Because Foucault (2011) states that the bodies are imprisoned and controlled simultaneously with the discourse of psychiatry and law. He emphasizes that the discourses of psychiatry affect the field of law and that bodies are manipulated. Undesirable bodies cannot take part in society and are labeled as patients.

Turner (2001) thinks that dualism, which begins with Descartes, should be added to sociology by integrating it into a field on continuum from 1960 onwards. Thus, the dualities in sociology turn into areas of difference and continuity. The sociology of the body, which began with Foucault in particular, has been deeply theoretical in Turner (2001) in a positive sense. Foucault (1993) emphasizes that in the historical process the medical discourse has been effective and directly or indirectly shapes the emergence of mental hospitals and prisons. He also tries to investigate that discourses determine and shape the body. Discourse in medicine causes the control of populations. Turner (2001) notes the fact that the body was forgotten in classical sociology. He states that although micro sociology has primarily stressed the importance of individuals, it has also largely ignored the body. He emphasizes in sociology that his emphasis on the body began after the 1960s. In fact, this period, which Turner $(1992,2011)$ determined, covers the years in which structuralism and modernity began to be criticized. In fact, Turner (2001) emphasizes that sociology is applied medicine in accordance with Foucault's thinking. In particular, the 
emergence of different disciplines and specializations in the field of medicine has led to a reorganization of the bodies. In a sense, the bodies were constantly controlled and the lives were medicalized.

In addition, a study of body sociology in modern and postmodern terms attempts to analyze sociology of bodies, based on Nietzche and Foucault. In future studies, women, identity, gender, cultural studies, education (students, teachers, and administrators) should be reinterpreted within the framework of body sociology. The transformation of a woman's body into a non-essentialist form within the sociology of the body can provide a better understanding of the sex performativity referred to by Butler (2008). Therefore, in Foucault (1993, 2003), Butler (2008) and Turner $(2001,2011)$, bodies are shaped by discourse practices and can be challenged by discourse. In this sense, women need public space and platforms where they can create their own discourse and express themselves. In the Butlerian sense, it is the different bodies and identities that have been forgotten.

\section{Kaynakça/References}

Butler, J. (1988). Performative act and gender constitution: An essay in phenomenology and feminist theory. Theatre Journal, 40 (4), 519531.

Butler, J. (2008). Cinsiyet belası. Başak Ertür (Çev.). İstanbul: Metis Yayıncilik.

Descartes, R. (2018). Felsefenin ilkeleri. Mesut Akın (Çev.). İstanbul: Say Yayınevi.

Descartes, R. (2011). Hakikatin araştırılması. Atakan Altınörs (Çev.). İstanbul: Paradigma Yayıncilik.

Durkheim, E. (1984). The division of labor in society. The Free Press.

Featherstone, M. (2005). Postmodernizm ve tüketim kültürü. Mehmet Küçük. (Çev.).İstanbul: Ayrıntı Yayınları.

Foucault, M. (1993). Cinselliğin tarihi. Hülya Tufan (Çev.).İstanbul: Afa Yayınları.

Foucault, M. (2003). Kliniğin doğuşu. Temel Keşoğlu (Çev.). Ankara: Doruk Yayımcilık. 
Foucault, M. (2011). Özne ve iktidar/Seçme Yazılar 2. Osman Akınhay ve Işık Ergüden (Çev.) İstanbul: Ayrıntı Yayınları.

Foucault. M. (2015). İktidarın gözü/Seçme Yazılar 4. Işık Ergüden (Çev.). İstanbul: Ayrıntı Yayınları.

Göle, N. (2000). İslamın yeni kamusal yüzleri: İslam ve kamusal alan üzerine bir atölye çalışması. İstanbul: : Metis Yayınları.

Göle, N. (2002). Melez desenler: İslam ve modernlik üzerine. İstanbul: Metis Yayınları.

Göle, N. (2004). Modern mahrem: Medeniyet ve örtünme. İstanbul: Metis Yayınları.

Göle, N. (2007). Batı-dışı modernlik kavramı üzerine. Tanıl Bora ve Murat Gültekin (Ed.). Modern Türkiye'de Siyasi Düşünce Batıcilık. İçinde (ss. 56-67). İstanbul: İletişim Yayınları.

Göle, N. (2009). İç içe girişler: İslam ve Avrupa. Ali Berktay (Çev.). İstanbul : Metis Yayınları.

Göle, N. (2015). Gündelik yaşamda Avrupalı Müslümanlar. Zehra Cunillera (Çev.) Istanbul: Metis Yayınları.

Honneth, A., ve Joas, H. 1988 [1980]. Social Action and Human Nature. Translated by Raymond Meyer. New York, NY: Cambridge University Press.

Marcuse, H. (2013). One-dimensional man: Studies in the Ideology of Advanced Industrial Society. London: Routledge.

Martin, E. (1989) The woman in the body: A cultural analysis of reproduction. Milton Keynes: Open University Press.

Merleau-Ponty, M. (1962). Phenomenology of perception. Trans.Colin Smith. London: Routledgea nd Kegan Paul.

Parsons, T. (1951). Social system. London: Routledge and Kegan Paul.

Shilling, C. (1993). The body and social theory. Londra: Sage.

Turner, B. S. (1992). Düzenleyen bedenler: sağllk sosyolojisinde denemeler. Barış Özkul (Çev.). İstanbul: İletişim Yayınları.

Turner, B. S. (2011). Tıbbi gü̈ç ve toplumsal bilgi. Ümit Tatlıcan (Çev.).Bursa: Sentez Yayıncilık.

Turner, B. S. (2001). Body and society. Londra: Sage Yaynlar1.

Williams, S.J. ve Bendelow G. (1998). The lived body: Sociological themes, embodied issues. London: Routledge. 


\section{Kaynakça Bilgisi / Citation Information}

Aydoğmuş-Ördem, Ö. (2018). Bryan S. Turner'ın kuramı çerçevesinde kadın, beden ve toplum. OPUS-Uluslararası Toplum Araştırmaları Dergisi, 9(16), 2556-2573. DOI: 10.26466/opus.488049 